\title{
マハラノビス-田口法を用いた炭素鋼腐食の水質診断法*
}

\author{
板垣昌幸 $* *$, 高宮枝里 $* *$, 渡辺邦洋 $* *$, 額賀孝訓***, 梅村文夫*** \\ ** 東京理科大学 理工学部 工業化学科 \\ *** 東京電力株式会社 技術開発研究所 材料技術グループ
}

\section{Diagnosis of Water Quality for Carbon Steel Corrosion by Mahalanobis-Taguchi Method*}

\author{
Masayuki Itagaki**, Eri Takamiya**, Kunihiro Watanabe**, \\ Takanori Nukaga*** and Fumio Umemura*** \\ ** Department of Pure and Applied Chemistry, Faculty of Science and Technology, Tokyo University of Science \\ *** Materials Engineering Group R\&D Center, Tokyo Electric Power Company
}

\begin{abstract}
Corrosion diagnostics of carbon steel in fresh water were carried out by Mahalanobis-Taguchi Method. Concentrations of sulfate ion, chloride ion and bicarbonate ion were used as items to judge the corrosion index. Artificial base areas were constructed by deciding standard deviations and the correlation coefficients arbitrarily. The items were classified into corrosion accelerator and corrosion inhibitor. "Closed" base area was constructed by using the axis of reciprocal concentration of corrosion inhibitor. The new method to construct on optimal base area artificially was developed. As the results to apply the present method to the experimental results of carbon steel in fresh water, the erroneous decision decreases remarkably comparing the conventional Mahalanobis-Taguchi Method.
\end{abstract}

Key word : corrosion diagnostic, Mahalanobis-Taguchi Method, carbon steel, corrosion, artificial base area.

1. 緒

言

淡水中における炭素鋼の腐食形態は，溶存イオン種や 温度，流速など複数の要因によって変化する。均一に腐 食が進行する全面腐食では，腐食の進行による劣化予測 が容易である。しかし，局部的に発生する孔食では予測 が困難であり漏水事故などの原因となるため, 淡水環境 下で使用される炭素鋼に対する水の腐食性評価が必要と されている．淡水中における金属の腐食要因である多次 元の項目を一次元の数で表すマハラノビス-田口法 (MT 法）を用いた腐食診断法が, 瓦井らによって提案された ${ }^{1}$. MT 法とは田口立一氏によって品質工学の分野で考案さ れ, 多変量成分を用いてマハラノビス距離を求めること により判別分析を行うものである. 実際の使用例として, 健康診断, 火災報知器および文字認識などが報告されて いる2).

MT 法を用いた淡水の腐食診断は，腐食防食協会での 多変量解析法検討会において議論が行われ，ステンレス 鋼，銅および炭素鋼などへの適用が目指されている．瓦 井ら1) はステンレス鋼および銅管における水の腐食性診 断を行い，MT 法によって腐食事例の判別が可能である ことを示した。熊谷ら ${ }^{3)-5)}$ はステンレス鋼および炭素鋼 について，2 成分の乗算值を交互作用項目として用いる ことにより誤判定を低減した。境 ${ }^{6)}$ は銅管の腐食に対し て, MT 法による水質データの判定を行った。 以上の報 告では，腐食に対する水質の判定を MT 法により行える

* 第 52 回材料と環境討論会 (北海道大学, 2005 年) で発表

** ７278-8510 野田市山崎 2641 (2641, Yamazaki, Noda, 278-8510 Japan)

*** = 230-8510 横浜市鶴見区江ヶ崎 4-1 (4-1, Egasaki, Tsurumi, Yokohama, 230-8510 Japan
可能性があることを十分に示しているが，結果に含まれ る誤判定も多く，腐食判定のための MT 法の実用化のた めには更なる高精度化が望まれる。

従来の MT 法では実際のサンプリングによりデー夕を 収集して基準空間の作成を行っているため，次の問題点 が含まれる。（1）収集したデー夕は地域により偏りがあ ると考えられるため，デー夕数が多いほど良い基準空間 が作成されるとは限らない。(2) 重炭酸イオンなど腐食 を抑制する要因は，基準空間に適した值の範囲を限定で きない，つまり開いた基準空間になってしまい，標準偏 差の意味を持たなくなってしまう。（3）基準空間を作成 する際は，デー夕 1 つ 1 つを問題としているわけではな い。実際に使用しているのは，基準空間データにおける 各項目の平均值，標準偏差および相関係数のみである. 以上より本報では, 平均值, 標準偏差および相関係数を 任意に定めた人工的な基準空間作成法を提案する。

\section{2. 原理・理 論}

\section{1 マハラノビス距離の算出と人工的な基準空間の作 成法}

$\mathrm{i}$ 番目の判別データのマハラノビス距離は式(1)で表さ れる7).

$$
D_{\mathrm{i}}^{2}=\frac{1}{k} \sum_{\mathrm{p}=1}^{k} \sum_{\mathrm{q}=1}^{k} a_{\mathrm{pq}} X_{\mathrm{p}} X_{\mathrm{q}}
$$

ここで $k$ は水質成分の個数， $a_{\mathrm{pq}}$ は基準空間における相 関係数の逆行列成分 ( $\mathrm{p}$ 行 $\mathrm{q}$ 列)， $X$ は正規化した後の水 質成分を表す。また，正規化は式(2)を用いて行う。

$$
X_{\mathrm{ij}}=\frac{x_{\mathrm{ij}}-\overline{y_{\mathrm{j}}}}{\sigma_{\mathrm{j}}}
$$

$x_{\mathrm{ij}}$ は成分 $\mathrm{j}(\mathrm{j}=1,2, \cdots, k)$ の水質因子， $\bar{y}_{\mathrm{j}}$ は基準空間 における成分 $\mathrm{j}$ の平均值， $\sigma$ は基準空間における成分 $\mathrm{j}$ の 
(a)

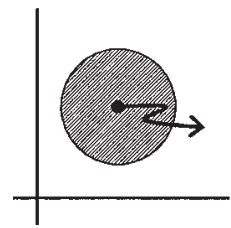

(b)

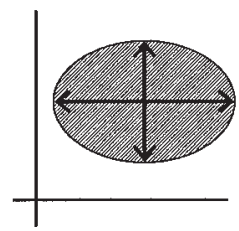

(c)

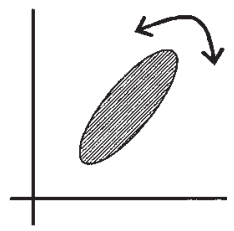

Fig. 1 The schemes of two-dimensional base area. (a) The base area with variation of meaning, (b) The base area varied by the standard deviation, and (c) The base area varied by the correlation coefficient.

標準偏差を示す。ここで本報ではマハラノビス距離を $M D$ と表現する $\left(M D\right.$ は $D_{\mathrm{i}}^{2}$ と同意である $)$. 式(1)および (2)より, 判別データの $M D$ に影響を及ぼすのは, 基準

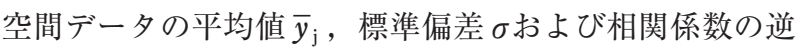
行列成分 $a_{\mathrm{pq}}$ の 3 項目となることがわかる. Fig. 1 に 2 次 元で表した基準空間の概念図を示す。平均值を変化させ ることは，基準空間の中心を移動させることを意味する. 標準偏差を変化させることは, 基準空間の大きさを変化 させることに対応する. また, 相関係数は基準空間の傾 きを意味する。本報では，これらの值を任意に変化させ ることによって，人工的な基準空間を作成した。このと きの計算には Microsoft Excel を使用した。比較のために 実施した従来法1, 3)-7) による $M D$ 計算には, (株)オーケ ン MTS for Windows 解析ソフトを用いた.

\section{2 使用する項目の選択}

炭素鋼の腐食に影響を及ぼす淡水中の溶存成分とし て, $\mathrm{Cl}^{-}, \mathrm{SO}_{4}{ }^{2-}, \mathrm{HCO}_{3}{ }^{-}, \mathrm{Ca}^{2+}$, 溶性シリカおよび $\mathrm{pH}$ な どが挙げられる ${ }^{8)}$. 本報では, 炭素鋼の腐食に特に影響 を及ぼすと考えられる $\mathrm{Cl}^{-}, \mathrm{SO}_{4}{ }^{2-}$ および $\mathrm{HCO}_{3}{ }^{-}$の 3 項目 を用いた。作成した基準空間の評価および従来法による $M D$ 算出には, 熊谷らの炭素鋼腐食試験結果 ${ }^{4), 5)}$ を使用 した。ここで酸消費量は式 (3)を用いて重炭酸イオン濃 度に変換した。

重炭酸イオン濃度/ppm

$$
=\frac{61}{50} \times \text { 酸消費量 }\left(\mathrm{asCaCO}_{3} / \mathrm{ppm}\right)
$$

熊谷らはしきい值に基準空間の $M D$ の最大値を使用し ている. 基準空間の $M D$ は最大で $3 \sim 4$ であり, 本法は 基準空間の $M D$ を算出しないため, 腐食の有無を判別す る $M D$ のしきい值を 3 と固定した.

\section{3 腐食促進因子と腐食抑制因子の扱い}

淡水中の溶存成分は，多く含まれるほど腐食を促進す るものと腐食を抑制するものに分けることができる. Fig. 2 に腐食抑制成分 $\left(\mathrm{HCO}_{3}{ }^{-}\right)$および腐食促進成分 $\left(\mathrm{Cl}^{-}\right)$を項目に使用した基準空間の模式図を示す。腐食 しない水質を正常として基準空間を作成した場合，腐食 促進成分の濃度は有限値となる。しかし腐食抑制成分に 関しては，あるしきい值以上が正常とみなされるため正 常範囲を定めることができないので, 腐食抑制成分を含 む場合には開いた基準空間となる (Fig. $2(\mathrm{a})$ )。従って, 腐食抑制成分の濃度を逆数にして使用することを提案す る。それにより基準空間に含まれる項目の正常範囲がす べて有限となる (Fig. 2(b)).

(a)

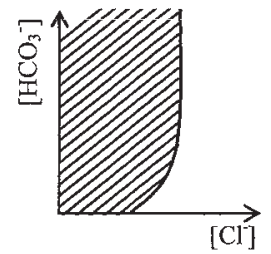

(b)

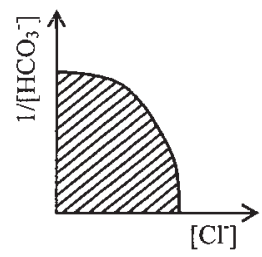

Fig. 2 The schemes of two-dimensional base area. (a) "open" base area including corrosion inhibitor, and (b) "close" base area by using the axis of inverse of corrosion inhibitor.

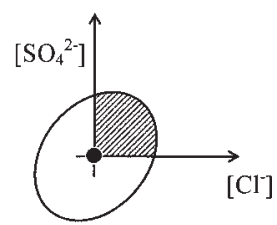

Fig. 3 The scheme of two-dimensional base area when the center is fixed at origin.

\section{4 基準空間の中心}

水質因子 $\mathrm{j}$ の平均值はデー夕母集団の個性に影響され る. 本報では平均値を理論的に決定し, 基準空間の最適 化を図る，例えば，炭素鋼の淡水腐食試験結果 ${ }^{4}$, 5) にお ける基準空間での塩化物イオン濃度の平均は $3.8 \mathrm{ppm}$ で あるが, 塩化物イオン濃度がこの值を下回る場合でも $M D$ の増加因子となりうる.このことは腐食工学におけ る経験的事実と明らかに異なる。すなわち, 塩化物イオ ン濃度に最適值はなく, 濃度が大きい程, 腐食発生のリ スクは増加する．そこで本報では基準空間の中心を 0 と して（腐食促進因子の平均值を 0 , 腐食抑制因子の逆数 の平均値を 0), 基準空間の広がりを標準偏差で表した. このときの 2 次元の基準空間の概念図を Fig. 3 に示す. 硫酸イオンと塩化物イオンの 2 項目に注目した場合, 斜 線部分は腐食が起こらない濃度範囲である. 実デー夕に おける硫酸イオン濃度と塩化物イオン濃度は正の值をと るため, 必然的にそれらの平均值は正の值となる。本報 では，仮想的に濃度を決定するため，この制限を受けず 平均值を 0 と定めることができる。この意味では「基準 空間での平均値」は，本報では「基準空間の中心」と定 義するべきであろう.

\section{3. 結 果と考察}

\section{1 従来法による基準空間の作成と判別}

(株)オーケン MTS for Windows 解析ソフトを使用して 計算した従来法による判別結果を Fig. 4 に示す。基準空 間は「腐食しない」デー夕 17 件を用いて作成した。判 別デー夕には「腐食しない」および「腐食する」データ 40 件を使用した。「腐食しない」デー夕は No Corrosion (17 件) と表し, 「腐食する」データ 23 件の水質は, 腐 食形態ごとに, Pitting corrosion(7 件), Pitting corrosion in general corrosion (11 件), General corrosion (3 件) お了 よび Heterogeneous corrosion (2 件) と分類されている4). 腐食の有無を分けるしきい值は $M D=3$ とした。これよ り, $M D<3$ となる範囲では「腐食しない」, $M D \geqq 3$ とな 


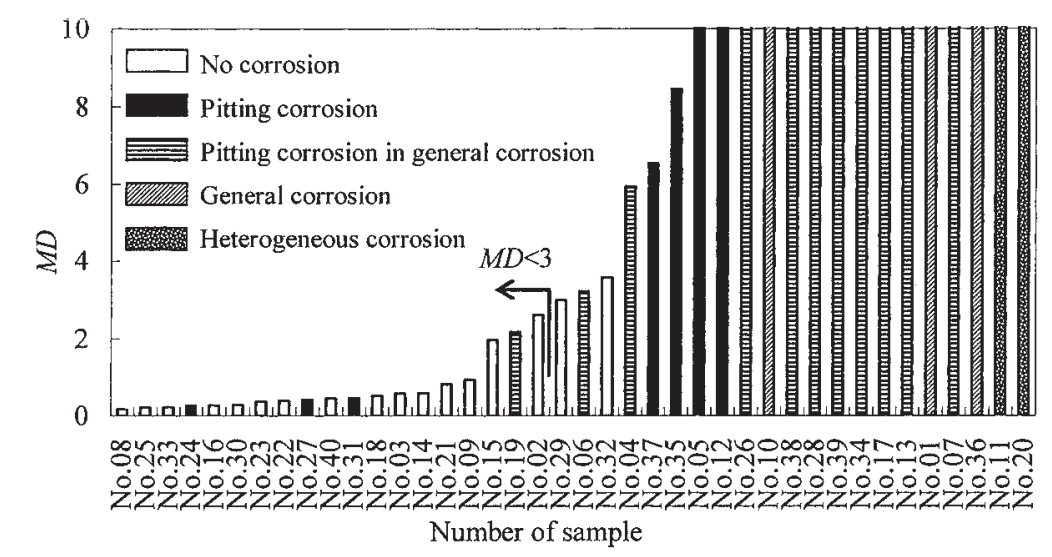

Fig. 4 Mahalanobis distances calculated by the conventional method for MahalanobisTaguchi System.

る範囲では「腐食する」と判定する. Fig. 4 より腐食試 験結果では「腐食する」とされた水質が「腐食しない」 と判定された誤判定は 4 件 (No. 24, No. 27, No.31, No. 19）であった。一方，「腐食しない」とされた水質が 「腐食する」と判定された誤判定は 2 件（No. 29, No. 32） であった。

\section{2 標準偏差の検討}

基準空間の中心をすべて 0 と定め，炭素鋼の淡水腐食 試験結果 ${ }^{4)}$ の「腐食しない」データ 17 件における $\left[\mathrm{SO}_{4}{ }^{2-}\right],\left[\mathrm{Cl}^{-}\right]$および $1 /\left[\mathrm{HCO}_{3}{ }^{-}\right]$の標準偏差をそれぞ れ変化させて MD を計算した。変化させる水質因子 $\mathrm{j}$ 以 外は従来法により計算された標準偏差および相関係数を 使用した。硫酸イオンの標準偏差を変化させたときの水 質データごとの $M D$ を Fig. 5 に示す. Fig. $5(\mathrm{a})$ には「腐 食しない」データの $M D$ を示す。ここでは任意の標準偏 差において $M D$ が 3 以上のものは「腐食する」水質であ ることを表すため, 誤判定となる.一方, Fig. 5(b)には
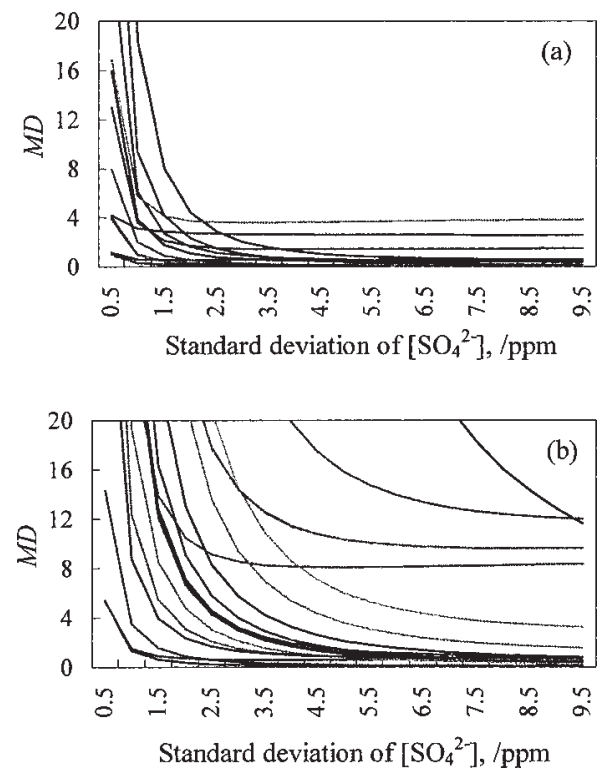

Fig. 5 Mahalanobis distances varied by the standard deviation of sulfate ion concentration. (a) "No corrosion" data, and (b) "Corrosion" data.
「腐食する」デー夕の $M D$ を示す。ここでは逆に $M D$ が 3 より小さいものが誤判定となる. 標準偏差が大きくな ると基準空間が広がるため, Fig. $5(\mathrm{a})$ と (b)での $M D$ は すべてのデータにおいて減少傾向を示す. 以上の議論よ り適正な標準偏差には中庸的な值が存在し, 誤判定が最 少となる標準偏差を最適なものとした。

\section{3 相関係数の検討}

炭素鋼の淡水腐食試験結果4) の「腐食しない」データ 17 件における $\left[\mathrm{Cl}^{-}\right]$対 $\left[\mathrm{SO}_{4}{ }^{2-}\right], 1 /\left[\mathrm{HCO}_{3}{ }^{-}\right]$対 $\left[\mathrm{SO}_{4}{ }^{2-}\right]$ および $1 /\left[\mathrm{HCO}_{3}{ }^{-}\right]$対 $\left[\mathrm{Cl}^{-}\right]$の相関係数を変化させ, 誤 判定が最少となる相関係数の組み合わせを探索した。こ のとき標準偏差は 3.2 で求めたものを使用した。 $\left[\mathrm{Cl}^{-}\right]$ 対 $\left[\mathrm{SO}_{4}{ }^{2-}\right]$ の相関係数を変化させたときの水質データ ごとの $M D$ を Fig. 6 に示す. 相関係数が $-0.9 \sim-0.3$ で は $M D$ が負の值をとり，- 0.3 以上になるとすべて正の 值をとっていることがわかる. $M D$ は 2 乗で定義される

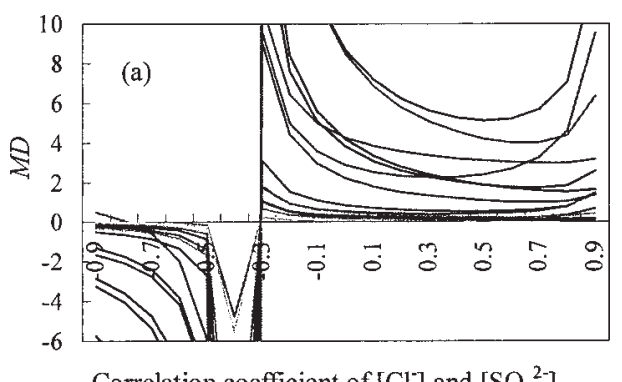

Correlation coefficient of $\left[\mathrm{Cl}^{-}\right]$and $\left[\mathrm{SO}_{4}{ }^{2-}\right]$

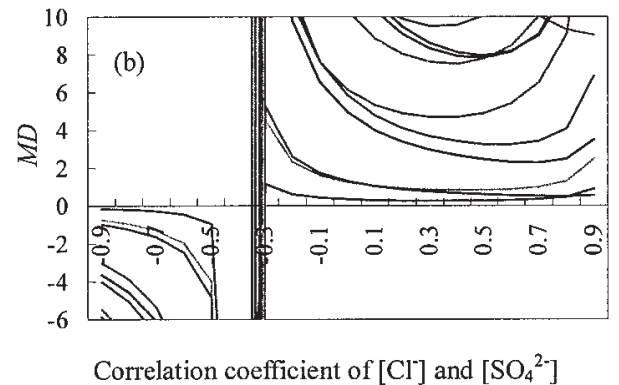

Fig. 6 Mahalanobis distances varied by the correlation coefficient of sulfate and chloride ions concentration. (a) "No corrosion" data, and (b) "Corrosion" data. 
Table 1 Standard deviations and correlation coefficients of the base area. Left side values were decided by the commercial software with the real data. Right side values were decided independently as the optimal values.

\begin{tabular}{|c|c|c|}
\hline & $\begin{array}{l}\text { Standard deviation of } \\
\text { base space decided by } \\
\text { real data }\end{array}$ & $\begin{array}{l}\text { Standard deviation of } \\
\text { artificial base space by } \\
\text { the present concept } \\
\text { (ppm) }\end{array}$ \\
\hline$\left[\mathrm{SO}_{4}{ }^{2-}\right]$ & 2.2 & 5 \\
\hline$\left[\mathrm{Cl}^{-}\right]$ & 4.0 & 6 \\
\hline $1 /\left[\mathrm{HCO}_{3}{ }^{-}\right]$ & 0.126 & 0.015 \\
\hline
\end{tabular}

\begin{tabular}{|c|c|c|}
\hline & $\begin{array}{l}\text { Correlation coeffi- } \\
\text { cient of base space } \\
\text { decided by the real } \\
\text { data }\end{array}$ & $\begin{array}{l}\text { Correlation coeffi- } \\
\text { cient of artificial } \\
\text { base space by the } \\
\text { present concept }\end{array}$ \\
\hline$\left[\mathrm{Cl}^{-}\right]$vs. $\left[\mathrm{SO}_{4}{ }^{2-}\right]$ & 0.42 & 0.6 \\
\hline $1 /\left[\mathrm{HCO}_{3}{ }^{-}\right]$vs. $\left[\mathrm{SO}_{4}{ }^{2-}\right]$ & -0.32 & -0.3 \\
\hline $1 /\left[\mathrm{HCO}_{3}{ }^{-}\right]$vs. $[\mathrm{Cl}]$ & -0.29 & -0.3 \\
\hline
\end{tabular}

值であるため負の数にはならないので, 相関係数では取 りうる值が範囲を持つことがわかる. Fig. 6 より $\left[\mathrm{Cl}^{-}\right]$ 対 $\left[\mathrm{SO}_{4}{ }^{2-}\right]$ の相関係数は -0.3 以上となる.

\section{4 標準偏差および相関係数を個別に検討し, 作成し た基準空間による判別}

$\left[\mathrm{SO}_{4}{ }^{2-}\right],\left[\mathrm{Cl}^{-}\right]$および $1 /\left[\mathrm{HCO}_{3}{ }^{-}\right]$の標準偏差およ び相関係数をそれぞれ誤判定が最少となるように個別に 検討した結果を Table 1 に示す。ここでは, 注目する標 準偏差または相関係数以外は，3.1で求めた值を用いた。 従来の方法で作成した基準空間よりも硫酸イオンおよび 塩化物イオンの標準偏差が大きくなっており，基準空間 が大きくなっている. Table 1 を用いて人工的に基準空間 を作成し，「腐食する」および「腐食しない」を共に含 む水質データ 40 件の判別を行うことで基準空間を評価 した. Fig. 7 に人工的な基準空間を用いて判別した水質 データの $M D$ を示す．その結果，「腐食する」を「腐食 しない」とする誤判定が従来法では 4 件であったのに対 し 7 件 (No. 27, No. 10, No. 24, No. 37, No. 31, No. 35, No. 5）と増加した。また「腐食しない」を「腐食する」と する誤判定は 2 件 (No. 3, No. 14) となり, 従来法と変

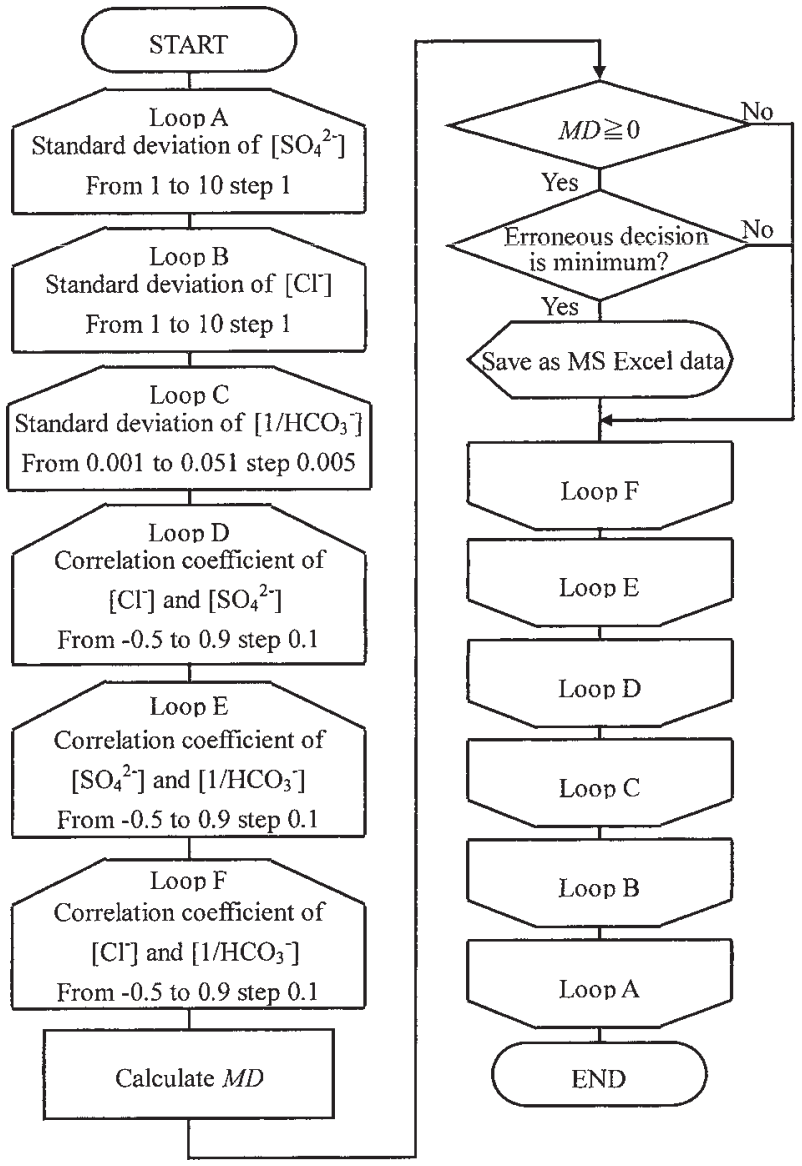

Fig. 8 The algorithm for the program to decide the optimal base area.

わらなかった。これは各イオンの標準偏差および相関係 数を個別に変化させたためである. そのため各項目は同 時に検討する必要があると考えられる.

\section{5 項目を同時に検討する人工的な基準空間の作成方 法}

各項目の值を同時に変化させるために Fig. 8 に示すア ルゴリズムを用いた。まず各イオンにおける標準偏差お よび相関係数の初期値, 終了值および増分を变数として

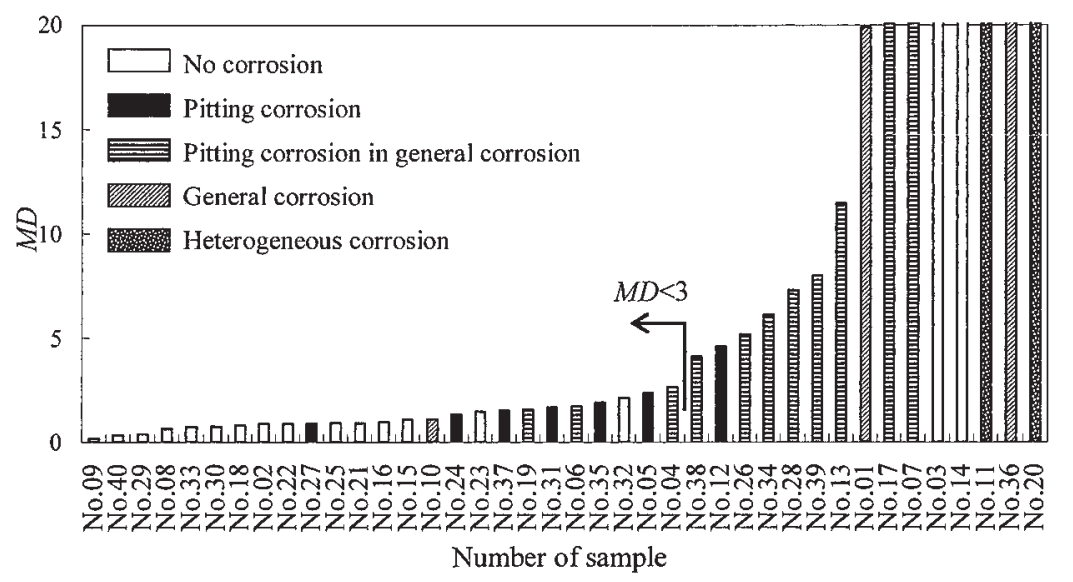

Fig. 7 Mahalanobis distances calculated by using artificial base area deciding the standard deviation and the correlation coefficient independently. 
Table 2 Standard deviations and correlation coefficients calculated by artificial base area whose center is fixed at origin. Left side values were decided by the commercial software with the real data. Right side values were decided independently as the optimal values.

\begin{tabular}{|c|c|c|}
\hline & $\begin{array}{l}\text { Standard deviation of } \\
\text { base space decided by } \\
\text { real data } \\
\text { (ppm) }\end{array}$ & $\begin{array}{l}\text { Standard deviation of } \\
\text { artificial base space by } \\
\text { the present concept } \\
\text { (ppm) }\end{array}$ \\
\hline$\left[\mathrm{SO}_{4}{ }^{2}\right]$ & 2.2 & 4 \\
\hline$\left[\mathrm{Cl}^{-}\right]$ & 4.0 & 8 \\
\hline$\left[\mathrm{HCO}_{3}{ }^{-}\right]$ & 41 & 70 \\
\hline
\end{tabular}

\begin{tabular}{|c|c|c|}
\hline & $\begin{array}{l}\text { Correlation coeffi- } \\
\text { cient of base space } \\
\text { decided by the real } \\
\text { data }\end{array}$ & $\begin{array}{l}\text { Correlation coeffi- } \\
\text { cient of artificial } \\
\text { base space by the } \\
\text { present concept }\end{array}$ \\
\hline$\left[\mathrm{Cl}^{-}\right]$vs. $\left[\mathrm{SO}_{4}{ }^{2-}\right]$ & 0.42 & -0.4 \\
\hline$\left[\mathrm{HCO}_{3}{ }^{-}\right]$vs. $\left[\mathrm{SO}_{4}{ }^{2-}\right]$ & 0.63 & 0.8 \\
\hline$\left[\mathrm{HCO}_{3}{ }^{-}\right]$vs. $\left[\mathrm{Cl}^{-}\right]$ & 0.46 & -0.1 \\
\hline
\end{tabular}

定めた。この変数を，標準偏差および相関係数のすべて の組み合わせで変化させた．変数を変化させるごとに基 準空間を作成し，これを用いて 40 データすべての $M D$ を計算した。ここで $M D>0$ であることを確認し，そう でない場合は変数を変化させて $M D$ を再計算した。この ように算出した $M D$ より誤判定数を算出するため,「腐 食する」データの $M D<3$ である個数抢よび「腐食しな い」デー夕の $M D \geqq 3$ である個数を求めた。このときの 誤判定数の合計をこの計算時までの最少の誤判定数と比 較した。ここで誤判定が減少した場合に各イオンの標準 偏差，相関係数および $M D$ を記録した．以上の計算を繰 り返し，変数をすべての組み合わせで変化させ，誤判定 が最少となったときの水質 3 項目における標準偏差およ び相関係数を最適な基準空間として採用した.

$\left[\mathrm{SO}_{4}{ }^{2-}\right],\left[\mathrm{Cl}^{-}\right]$および $\left[\mathrm{HCO}_{3}{ }^{-}\right]$の 3 項目を使用して 作成した人工的な基準空間㧍よび従来の基準空間を Table 2 に示す．従来法による基準空間の平均值は，「腐 食しない」データより計算したものを使用した。 人工的 な基準空間ではいずれの標準偏差も值が大きくなってい るため, 従来の基準空間よりも範囲が広がっていること がわかる. Fig. 9 に人工的な基準空間を用いて算出した
Table 3 Standard deviations and correlation coefficients calculated by artificial base area. The center of base area is fixed at origin and the one of axes is the inverse of bicarbonate ion concentration. Left side values were decided by the commercial software with the real data. Right side values were decided independently as the optimal values.

\begin{tabular}{|c|c|c|}
\hline & $\begin{array}{l}\text { Standard deviation of } \\
\text { base space decided by } \\
\text { real data } \\
(\mathrm{ppm})\end{array}$ & $\begin{array}{l}\text { Standard deviation of } \\
\text { artificial base space by } \\
\text { the present concept } \\
\text { (ppm) }\end{array}$ \\
\hline$\left[\mathrm{SO}_{4}{ }^{2}\right]$ & 2.2 & 3 \\
\hline$\left[\mathrm{Cr}^{-}\right]$ & 4.0 & 5.5 \\
\hline $1 /\left[\mathrm{HCO}_{3}{ }^{-}\right]$ & 0.126 & 0.011 \\
\hline
\end{tabular}

\begin{tabular}{|c|c|c|}
\hline & $\begin{array}{l}\text { Correlation coeffi- } \\
\text { cient of base space } \\
\text { decided by the real } \\
\text { data }\end{array}$ & $\begin{array}{l}\text { Correlation coeffi- } \\
\text { cient of artificial } \\
\text { base space by the } \\
\text { present concept }\end{array}$ \\
\hline$\left[\mathrm{Cl}^{-}\right]$vs. $\left[\mathrm{SO}_{4}{ }^{2-}\right]$ & 0.42 & -0.4 \\
\hline $1 /\left[\mathrm{HCO}_{3}^{-}\right]$vs. $\left[\mathrm{SO}_{4}{ }^{2-}\right]$ & -0.32 & 0.8 \\
\hline $1 /\left[\mathrm{HCO}_{3}\right]$ vs. $\left[\mathrm{Cl}^{2}\right]$ & -0.29 & -0.1 \\
\hline
\end{tabular}

MD を示す。「腐食する」を「腐食しない」とする誤判 定が, 従来の 4 件から本法では 3 件 (No. 24, No. 27, No. 31）に減少した。また，「腐食しない」を「腐食する」 とする誤判定が, 従来の 2 件から本法では 0 件に減少し た。誤判定が減少した理由として，基準空間の中心を 0 と固定することにより低濃度の攻撃性イオンを含むデー 夕に対する判定精度が向上したことが挙げられる。

$\left[\mathrm{SO}_{4}{ }^{2-}\right],\left[\mathrm{Cl}^{-}\right]$および $1 /\left[\mathrm{HCO}_{3}{ }^{-}\right]$の 3 項目を使用し て作成した人工的な基準空間を従来法による基準空間と 共に Table 3 に示す. Fig. 10 に人工的な基準空間を用い て算出した $M D$ を示す。「腐食する」を「腐食しない」 とする誤判定が，従来の 4 件から 1 件（No. 27）に減少 した。また，「腐食しない」を「腐食する」とする誤判 定は従来の 2 件から本法では 3 件 (No. 23, No. 3, No. 14) に増加した。腐食診断をするにあたり孔食等の腐食によ る事故を防止するという目的から，「腐食する」を「腐 食しない」とする誤判定が重大な事故原因となるものと 考えられる，以上から，炭素鋼の腐食抑制成分である重 炭酸イオンを逆数にし，各項目の平均值を 0 に固定した 本法により有用な結果が得られたといえる.

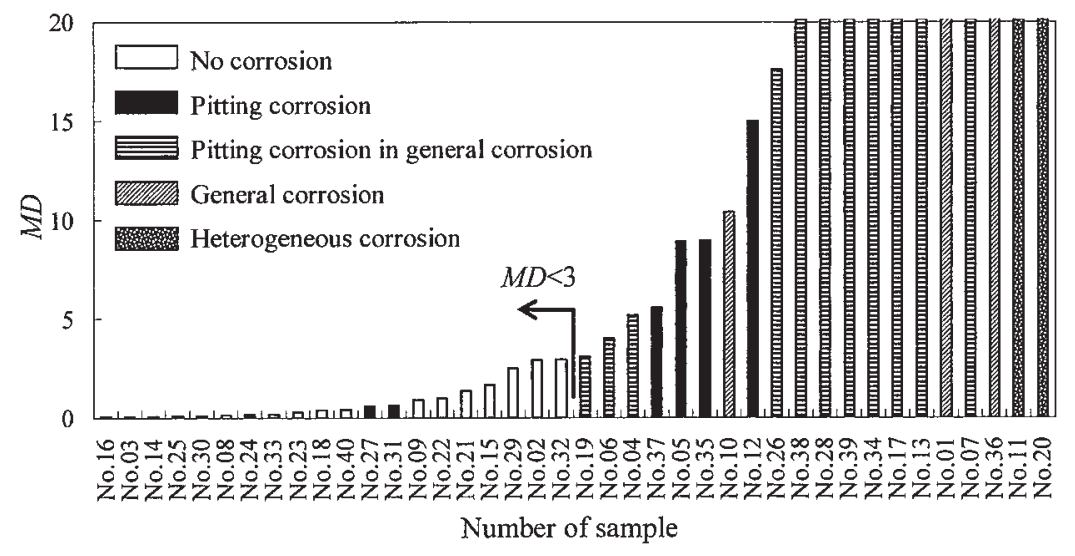

Fig. 9 Mahalanobis distances calculated by artificial base area whose center is fixed at origin. 


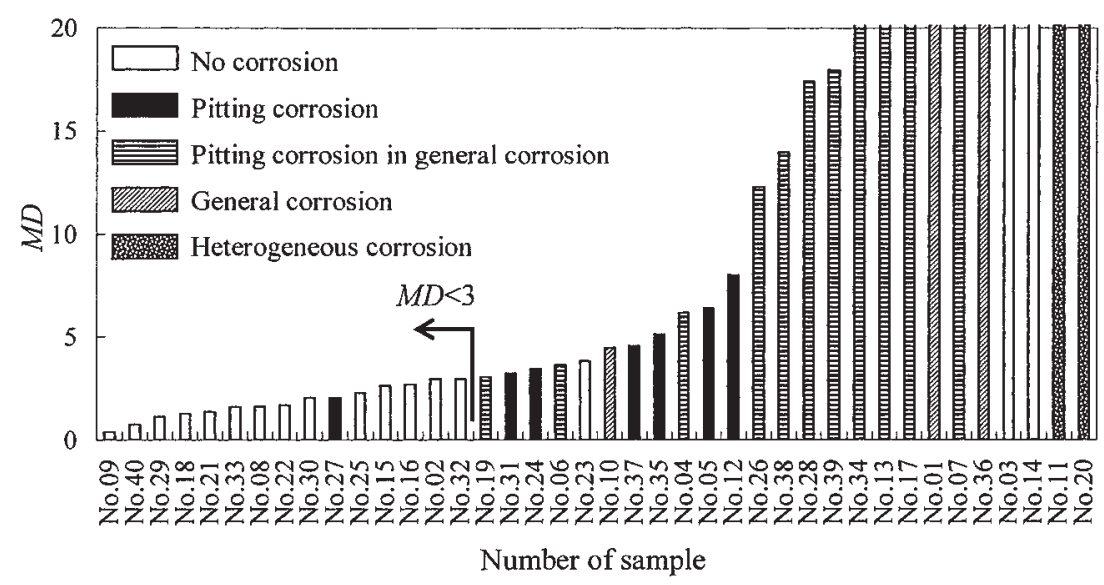

Fig. 10 Mahalanobis distances calculated by artificial base area. The center of base area is fixed at origin and the one of axes is the inverse of bicarbonate ion concentration.

今回使用した項目は硫酸イオン, 塩化物イオンおよび 重炭酸イオンの 3 項目であったが, 炭素鋼の腐食に影響 する因子としてほかに溶性シリカ，カルシウムイオン， $\mathrm{pH}$, 電気伝導度, 流速および温度等が挙げられる。この ため，さらに精度良く判別するには，項目選択を検討す る必要があるといえる。ささらに, 水質は季節や使用環境 によって変動するため, 炭素鋼の存在する環境ごとに最 適な基準空間を設定するべきである。しかし，実際には 基準空間となる「腐食しない」水質デー夕を数多く収集 するのは困難であるため，人工的に定められた基準空間 を用いる本報は実用的であるといえる。

また，算出した $M D$ のうち，誤判定となる「腐食する」 データは炭素鋼が孔食を起こしたもので毎回同一のもの であり, 特にNo. 24 No. 27 は同一水系の水質であること から，検討したイオン種以外の影響が考えられる.

\section{4. ま と め}

マハラノビス-田口法（MT 法）を用いた淡水中におけ る炭素鋼の腐食診断に以下の提案をした。

（1）任意の平均值，標準偏差および相関係数を用い て人工的な基準空間を作成し， $M D$ を計算した.

（2）腐食抑制因子は逆数にして扱うことで，閉じた 基準空間を作成することができる.

（3）基準空間の中心 (平均值）を０に固定することで 低濃度の腐食促進因子に対応した。
（4）腐食抑制因子の逆数を使用し, 中心を 0 に固定 した基準空間では，「腐食する」を「腐食しない」とす る誤判定が従来法より減少した.

MT 法は正常データの空間を定め (基準空間), 対照デ ー夕の包含および排除を判断するため, 腐食判定におい ては必然的に $100 \%$ 精度を得ることはできない。した がって計算法またはデータサンプリングの工夫からより 高い精度の達成を目指すべきである，また，実用化に向 けた腐食判定をするには，「腐食する」「腐食しない」と いう判定のほかに「グレーゾーン」を設け，判断しかね る水質として専門家による判断や再検討を行う必要があ るといえる。

\section{参 考 文 献}

1) H. Kawarai and S. Miki, Proc. 48th Japan Conf. Materials and Environments, p.355, JSCE (2001).

2）田口，MT システムに打ける技術開発，日本規格協会 (2002).

3) K. Kumagai and F. Umemura, Zairyo-to-Kankyo, 53, 560 (2004).

4) K. Kumagai, F. Umemura and T. Nukaga, Proceedings of JSCE Materials and Environments 2005, p.9, JSCE (2005).

5) K. Kumagai, F. Umemura and T. Nukaga, Zairyo-toKankyo, 55, 193 (2006).

6) M. Sakai, Proc. 52nd Japan Conf. Materials and Environments, p.453, JSCE (2005).

7) Q. Makoto, Quality Engineering, 9, 13 (2001).

8) S. Takasaki, Reito, 77, 17 (2002).

(Manuscript received November 1, 2005; in final form April 12, 2006)

\section{要旨}

マハラノビスー田口法（MT 法）を用いて，淡水中における炭素鋼の腐食診断を行った。検討する水質 項目として, 硫酸イオン, 塩化物イオンおよび重炭酸イオンの 3 項目を使用した. 任意の平均值, 標準偏 差および相関係数を用いることで人工的な基準空間を作成した。項目を腐食促進成分と腐食抑制成分に分 類し，腐食抑制成分を逆数にすることで閉じた基準空間とした．基準空間の中心（平均值）を 0 と固定す ることで，低濃度の腐食促進因子に対応した。最適な基準空間を人工的に作成する方法を構築した.この 方法を用いて炭素鋼の淡水腐食試験結果より評価を行った結果，誤判定が従来法よりも大幅に減少した.

$$
\text { キーワード＼cjkstart腐食診断，マハラノビス田口法，炭素鋼，基準空間 }
$$

